\title{
Variations in primary production of northern Gulf of Mexico continental shelf waters linked to nutrient inputs from the Mississippi River
}

\author{
Steven E. Lohrenz ${ }^{1, *}$, Gary L. Fahnenstiel ${ }^{2}$, Donald G. Redalje ${ }^{1}$, Gregory A. Lang ${ }^{3}$, \\ Xiaogang Chen ${ }^{1}$, Michael J. Dagg ${ }^{4}$ \\ 'University of Southern Mississippi, Institute of Marine Sciences, Stennis Space Center, Mississippi 39529, USA \\ ${ }^{2}$ Great Lakes Environmental Research Laboratory/NOAA, 1431 Beach St., Muskegon, Michigan 49441 USA \\ ${ }^{3}$ Great Lakes Environmental Research Laboratory/NOAA, 2205 Commonwealth Blvd, Ann Arbor, Michigan 48105, USA \\ ${ }^{4}$ Louisiana Universities Marine Consortium, 8124 Hwy 56, Chauvin, Louisiana 70344, USA
}

\begin{abstract}
Increases in nutrient concentrations in the Mississippi River over the past 35 yr have led to speculation that primary production of organic carbon has been elevated as a result of increased nutrient fluxes that have occurred in the northern Gulf of Mexico coastal ecosystem. However, studies thus far have not provided direct demonstration of temporal relationships between measured primary production in continental shelf waters and river-borne nutrient fluxes. This investıgation compared temporal variations in primary production with associated annual and interannual changes in riverborne nutrient inputs. Pramary production in shelf waters near the river delta were found to be signuficantly correlated with nitrate $\left(\mathrm{NO}_{3}{ }^{-}\right)+$nitrite $\left(\mathrm{NO}_{2}\right)$ concentrations and fluxes over a 6 yr period from 1988 to 1994. Although light limitation was probably an important factor during winter months, a positive correlation was demonstrated between river inputs of $\mathrm{NO}_{3}{ }^{-}+\mathrm{NO}_{2}{ }^{-}$and primary production for data collected from other times of the year. Peak nutrient inputs generally occurred in the spring. The magnitude of the riverborne $\mathrm{NO}_{3}{ }^{-}+\mathrm{NO}_{2}{ }^{-}$inputs averaged $106 \%$ of estimated nitrogen requirements for phytoplankton in the river-impacted region, considerably greater than in Amazon shelf waters, which have been less subject to anthropogenic nutrient increases. The possibility exists that further increases in anthropogenic nutrients in the Mississippi River could lead to higher and more widespread primary production, and this may intensify and extend the depletion of oxygen that has already been observed in the Louisiana shelf ecosystem. However, such a prediction is difficult because relationships between increasing nutnent inputs and primary production are unlikely to be linear, and a complete understanding of processes intermediate between primary production of organic matter and oxygen depletion in bottom waters on the Louisiana shelf is still lacking
\end{abstract}

KEY WORDS: Primary production - Nutrients - Phytoplankton - Continental shelf $\cdot$ Hypoxia Mississippi River Gulf of Mexico. Eutrophication

\section{INTRODUCTION}

Eutrophication of coastal ecosystems in the form of increased primary production, or photosynthetic fixation of inorganic carbon, is an expected consequence of increases in anthropogenic inputs of nutrients such as dissolved nitrate and phosphate. Long-term increases in land-derived nutrients in populated regions

·E-mail: steven.lohrenz@usm.edu have been observed in various estuarine and coastal systems (e.g. Dyer \& D'Elia 1994, Bricker \& Stevenson 1996). However, despite the fact that observations of eutrophication in offshore coastal waters were reported over 25 yr ago (Ryther \& Dunstan 1971), arguments have remained controversial that terrestrially derived nutrient inputs can impact coastal waters beyond those of enclosed and semi-enclosed water bodies. This can largely be attributed to the limited evidence for temporal linkages between primary pro- 
duction and nutrient inputs (Hinga et al. 1995). Indeed, there are few long-term data sets available for comparing primary production in continental shelf waters with nutrient inputs from terrestrial sources.

Coastal regions impacted by major rivers carrying substantial nutrient loads provide a likely setting for demonstrating relationships between terrestrially derived nutrients and primary production. However, even in the case of significant changes in riverborne nutrient fluxes, there are various reasons why relationships with coastal primary production may be difficult to demonstrate. For example, the impact of riverborne nutrients on rates of primary production may be diminished if nutrient supplies are supplemented by regenerated or offshore sources (e.g. Malone 1984, DeMaster \& Pope 1996). In addition, factors other than nutrient inputs may regulate and constrain productivity in river/estuarine systems. For example, low irradiance in turbid, low salinity outflow may constrain rates as has been reported previously for Mississippi River (Lohrenz et al. 1990) and Amazon River plumes (DeMaster et al. 1996, Smith \& DeMaster 1996). Additional factors such as herbivore grazing (Dagg 1995). stratification and circulation effects, and inhibition due to strong gradients in salinity or input of toxic substances (Riley 1937, Lohrenz et al 1990) may also influence rates independently of nutrient inputs.

The Mississippi River drains $41 \%$ of the contiguous United States, is the largest river in North America and ranks among the 7 largest of world rivers in discharge (van der Leeden et al. 1990). Increased anthropogenic inputs of nitrogen, coupled with alterations in the morphology of the river channel and changes in land use, have led to a doubling of nitrate concentrations over the past 35 yr (Turner \& Rabalais 1991, Dinnel \& Bratkovitch 1993, Bratkovich et al. 1994). Phosphorus levels have also increased (Turner \& Rabalais 1991, 1994a). The observed changes in nutrient concentrations in the river have led to speculation that increased primary production of organic carbon as a result of increased nutrient fluxes may have occurred in the northern Gulf of Mexico coastal ecosystem (Justic et al. 1993, 1994, Turner \& Rabalais 1994a Rabalais et al. 1996). To date, time-series comparisons of riverborne nutrient fluxes and coastal primary production in this system have been lacking Circumstantial evidence to support arguments for impacts on productivity includes the following: (1) direct measurements of high chlorophyll concentrations and enhanced primary production in the nutrient-rich outflow from the Mississippi River (Riley 1937, Thomas \& Simmons 1960, Lohrenz et al. 1990), (2) satellite imagery revealing an extensive area of river-impacted waters on the northern Gulf of Mexico continental shelf (Walsh et al. 1989, Müller-Karger et al. 1991, Lohrenz et al. 1998),
(3) significant spatial correlations between primary production and nitrate and silicate concentrations in shelf waters near the delta (Redalje et al. 1994), (4) long-term (50 to $100 \mathrm{yr}$ ) patterns in accumulation of biologically bound silica in dated sediment cores near the Mississippi River delta in support of a trend in increased primary production (Turner \& Rabalais 1994b), and (5) seasonal-scale coherence between freshwater discharge and net productivity estimated from oxygen time-series on the Louisiana shelf west of the delta (Justic et al. 1993). These studies fall short of providing a direct demonstration of a temporal relationship between riverborne nutrient fluxes and primary production in river-impacted waters.

Here, we provide the first evidence for a relationship between annual and interannual changes in nutrient fluxes from the Mississippi River and temporal variations in primary production in the adjacent coastal waters Comparison to historical observations of primary production near the Mississippi River delta support the premise that present day nutrient inputs and corresponding rates of primary production are elevated. The possibility exists that further increases in anthropogenic nutrients could lead to higher and more widespread primary production, and may accelerate and intensify the consequences of eutrophication that have already been observed in this ecosystem (Rabalais et al. 1994, 1996).

\section{MATERIALS AND METHODS}

The relationship between primary production and contemporaneous nutrient inputs associated with the Mississippi River outflow was examined by comparing estimates of primary production compiled from 16 cruises (Table 1) with nutrient concentrations and discharge estimates for the river. The data set spanned a 6 yr period from 1988 to 1994 and included efforts associated with various programs including the Louisiana Stimulus for Excellence in Research (LASER), the U.S. National Oceanic and Atmospheric Administration Nutrient Enhanced Coastal Ocean Productivity (NOAA/ NECOP) program, the U.S. Department of Energy Ocean Margins Program (DOE/OMP), and the U.S. Mineral Management Services Louisiana-Texas Shelf Circulation Study (MMS/LATEX).

Water column-integrated primary production was estimated in April 1988 using simulated in situ incubations with ${ }^{14} \mathrm{C}-\mathrm{HCO}_{3}$ - as previously described (Lohrenz et al 1990). For all other periods, daily primary production was determined using a photosynthesisirradiance technique (Lang \& Fahnenstiel 1996). The method required estimates of photosynthesis-irradiance $(P-I)$ parameters, surface irradiance and diffuse irradi- 
Table 1. Cruse information for primary production measurements

\begin{tabular}{|c|c|c|}
\hline Vessel & Crunse dates & Sponsoring program \\
\hline RV 'Pelican' & 16-24 Apr 1988 & LASER \\
\hline RV 'Pelican' & $20-27$ Sep 1989 & LASER \\
\hline RV 'Pelican' & $23-29$ Арг 1990 & LASER \\
\hline RV 'Pelican' & $23-29$ Oct 1990 & LASER \\
\hline RV 'Pelıcan' & $12-18$ Sep 1991 & NOAA/NECOP \\
\hline RV 'Pelican' & 12-19 Apr 1992 & NOAA/NECOP \\
\hline RV 'Pelican' & 5-18 May 1992 & NOAA/NECOP \\
\hline RV 'Pelıcan' & $19-27$ Oct 1992 & DOE/OMP \\
\hline RV 'Pelican' & 27 Mar-2 Apr 1993 & NOAA/NECOP \\
\hline RV 'Pelican' & 3-11 Apr 1993 & NOAA/NECOP \\
\hline RV 'Pelican' & 5-13 May 1993 & DOE/OMP \\
\hline NOAA Ship 'Malcom Baldrige' & $17 \mathrm{Jul}-10$ Aug 1990 & NOAA/NECOP \\
\hline NOAA Ship Malcom Baldrige' & $4-17 \operatorname{Mar} 1991$ & NOAA/NECOP \\
\hline RV 'Powell' & 25 Jul-6 Aug 1993 & MMS/LATEX \\
\hline RV 'Powell' & $6-21$ Nov 1993 & MMS/LATEX \\
\hline RV 'Powell' & 26 Jul-7 Aug 1994 & MMS/LATEX \\
\hline
\end{tabular}

ance attenuation coefficients at a given location. P-I parameters were determined at each productivity station by ${ }^{14} \mathrm{C}-\mathrm{HCO}_{3}{ }^{-}$incubation using the photosynthetron procedure (e.g. Lewis \& Smith 1983). Methods used for water collection during RV 'Pelican' and NS 'Malcolm Baldrige' cruises were as previously described (Lohrenz et al. 1994). During RV 'Powell' cruises, samples were collected using a General Oceanics, Inc. 12-place Rosette sampling system equipped with $10 \mathrm{l}$ Lever Action Niskin bottles. Additional information about methods for determining $P$ - $I$ parameters, surface irradiance, and diffuse irradiance attenuation coefficients has been given elsewhere (Lohrenz et al. 1994) With the data obtained for each station, the $P$-I model (Lang \& Fahnenstiel 1996) provided chlorophyll-specific rates of primary production $\left(P^{B}, \mathrm{mg}\right.$ carbon fixed $\mathrm{mg}^{-1}$ chlorophyll $\mathrm{h}^{-1}$ ) for depth increments of 0.5 to $1 \mathrm{~m}$. Photosynthetic rates were estimated as the product of $P^{\mathrm{B}}$ and chlorophyll concentration. Hourly rates were summed over the photoperiod to give daily production and water columnintegrated production was determined by trapezoidal integration of depth profiles. Results using the $P$-I method compared favorably (Fig. 1) with $24 \mathrm{~h}$ in situ and simulated in situ measurements of primary production. The simulated in situ measurements were determined as described previously (Redalje et al. 1994). In situ incubations were conducted using the same procedures, except that bottles were suspended at the sampling depth during daylight hours and transferred to darkened incubators after sunset. Both conventional bottle incubations and $P-I$ methods are subject to inherent variability and limitations (e.g. Lohrenz 1993) giving rise to the scatter in Fig. 1. Nevertheless, a model II regression of the data yielded a fit close to the $1: 1$ relationship. This consistency be- tween independent estimates of primary production supported the validity of the methods.

Methods for acquiring hydrographic data to estimate mixed layer depths for RV 'Pelican' and NS 'Malcolm Baldrige' cruises was described previously in Lohrenz et al. (1994). For RV 'Powell' cruises, profiles of conductivity/temperature/depth (CTD) were acquired using a Sea-Bird Electronics, Inc. 911 plus CTD. For all cruises, mixed layer depths were estimated by visual inspection of sigma-t profiles. Mean mixed layer irradiance was estimated by computing the depthintegrated subsurface irradiance attenuated through the mixed layer and dividing by the mixed layer depth.

\section{RESULTS}

Data for primary production were grouped into 3 geographical regions (Fig. 2) to facilitate comparisons among cruises with differing spatial coverage. The central $\left(4400 \mathrm{~km}^{2}\right)$ and eastern $\left(2400 \mathrm{~km}^{2}\right)$ regions were adjacent to the birdfoot delta and likely to

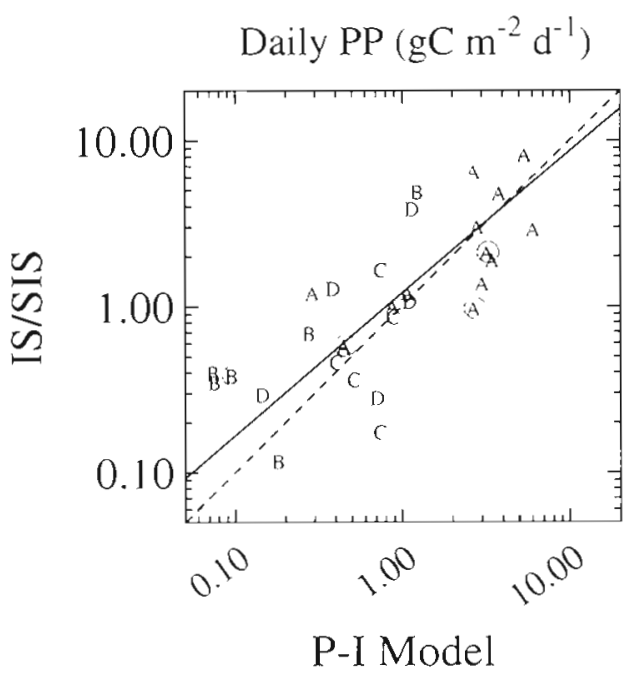

Fig. 1. Comparison of primary production estimated using the photosynthesis-irradrance $(P-I)$ technique compared with conventional measurements from in situ (IS) or simulated in situ (SIS) incubations. Symbols correspond to different cruise periods in Table 1 (A, Jul/Aug 1990; B, Mar 1991; C, Sep 1991; D, May 1992). Circled symbols are the in situ data. Dashed line illustrates $1: 1$ relationship. The correlation coefficient $\left(\mathrm{r}^{2}\right)$ of natural logarithm-transformed data was 0.563 ( $p<0.001$, $N=31$ ). The logarithmic transformation was required to normalize variances. The solid line represents the model II regression (Laws 1997) as described by the equation $y=1.2 x^{0.856}$ 


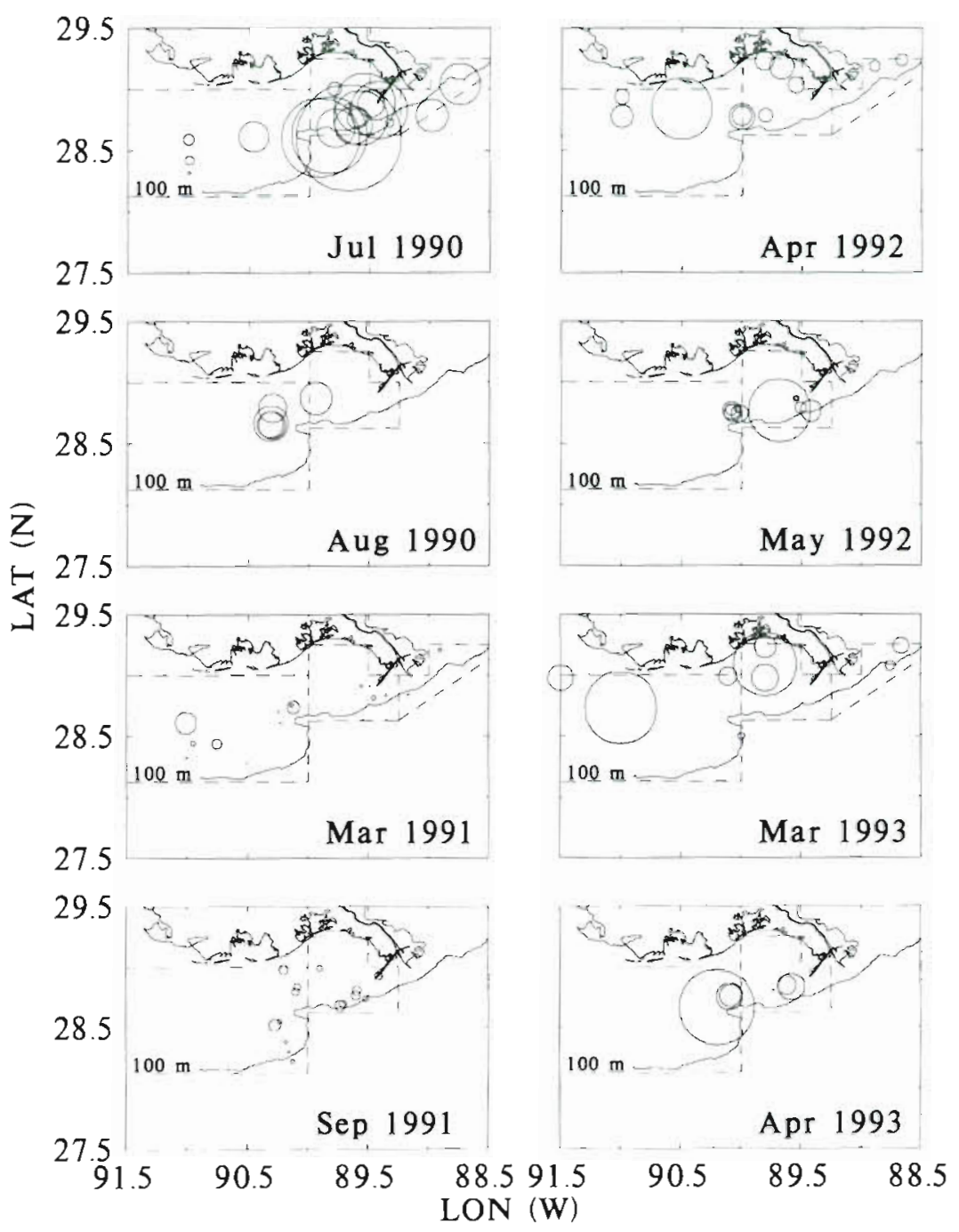

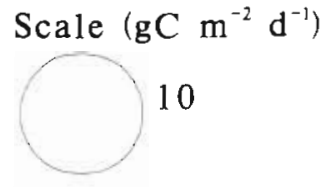

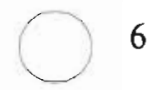

6

3

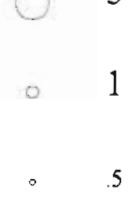

Fig. 2. Bubble plot of primary production in shelf waters of the northern Gulf of Mexico near the Missıssippi River delta region. For brevity, only data collected on cruises conducted as part of the NOAA/NECOP study were shown. Data from these and other cruises listed in Table 1 were used in the analysis. Dashed lines designate the boundaries of the western, central and eastern geographic regions as discussed in text receive the direct impact of the river outflow. The western region $\left(14300 \mathrm{~km}^{2}\right)$ covered the Louisiana shelf from 90 to $91.5^{\circ} \mathrm{W}$ longitude. Because a major portion of the river discharge can flow to the west (Müller-Karger et al. 1991, Walker \& Rouse 1993), this region was included for comparative purposes.

Mississippi River discharge exhibited a seasonal. pattern of high flow during winter and spring, decreasing flow in mid-year and lowest flow during late summer and fall (Fig 3a). River $\mathrm{NO}_{3}{ }^{-}+\mathrm{NO}_{2}{ }^{-}$concentrations varied in a seasonal. cycle with highest values generally occurring in late spring or summer. Inorganic nitrogen flux into the designated region was computed by multiplying the discharge by the $\mathrm{NO}_{3}+\mathrm{NO}_{2}^{-}$concentrations (Fig. 3b). Ammonium accounted for a small fraction of the total inorganic nitrogen flux, ranging from 0.4 to $6 \%$ for 1988 to 1994 USGS data from Venice, Louisiana (data not shown), and was not included in the estimate. The resulting values exhibited a temporal pattern similar to discharge, although peak fluxes sometimes lagged discharge by as much as 1 mo. The lag was unlikely to be due to temporal offsets between nutrient and flow monitoring locations along the river mouth as this would amount to only a few days (S. Dinnel pers comm.). Mean primary production ranged from 0.3 to $3.8 \mathrm{gC} \mathrm{m}^{-2} \mathrm{~d}^{-1}$ in both the eastern and central regions and 0.6 to $3.3 \mathrm{gC} \mathrm{m}^{-2} \mathrm{~d}^{-1}$ in the western region (Fig. 3b) Highest values of primary production were generally observed during the months of April-July, and lower values were observed during September-October Values were also low in March 1991 To simplify the ensuing data analyses, it was assumed that both the eastern and central regions exhibited similar characteristics representative of waters directly impacted by river outflow. Differences between means for these regions were not significant (Table 2). The data from the 2 regions were pooled for subsequent comparisons.

Mean primary production for the combined central/ eastern region exhibited an increasing trend with in- 


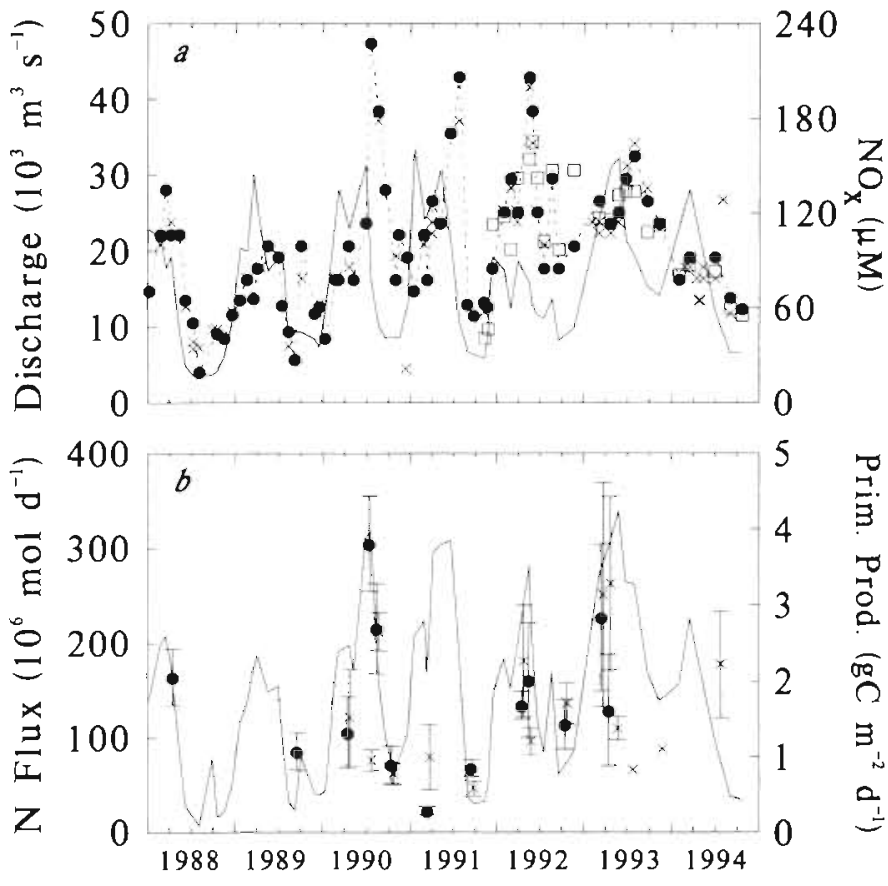

Date
Fig. 3. (a) Time-series of Mississippı River discharge (solid line) measured at Tarbert Landing, MS (courtesy of the US Army Corps of Engineers) for the period from 1988 to 1994. Concentrations of $\mathrm{NO}_{4}^{-}+\mathrm{NO}_{2}$ were shown for monitoring locations on the river including Vence ( $\bullet$ ) and Belle Chasse, LA $(x)$. Venice is located $17 \mathrm{~km}$ upstream of 'Head of Passes', i.e. the point of divergence of passes on the birdfoot delta. Belle Chase is located approximately $105 \mathrm{~km}$ upstream of Venice. The dashed line traces the Venice $\mathrm{NO}_{3}{ }^{-}+\mathrm{NO}_{2}$ data to highlight trends. Data for nutrients were provided by the US Geological Survey in Baton Rouge, LA (C. Demas \& C. Garrison pers comm.). Methods for analyses have been described previously (Fishman \& Friedman 1989). Independent data for $\mathrm{NO}_{3}{ }^{-}$concentrations (a) provided by the Jefferson Parish Water Quality Laboratory, Jefferson, LA (about $150 \mathrm{~km}$ upstream of Venice) show good agreement with the USGS data. (b) Riverborne flux of $\mathrm{NO}_{3}+\mathrm{NO}_{2}$ (solud line) computed from data in (a) for the penod from 1988 to 1994. Average of daily integrated primary production is shown for the combined central and eastern regions $(\bullet)$ and western region $(x)$. Boundaries for regions are given in Fig. 1 Errors indicate $\pm 1 \mathrm{SE}$ creasing river $\mathrm{NO}_{3}{ }^{-}+\mathrm{NO}_{2}{ }^{-}$flux (Fig. 4 a). The correlation between primary production and $\mathrm{NO}_{3}{ }^{-}+\mathrm{NO}_{2}{ }^{-}$flux was statistically significant provided that the anomalously low value observed during March 1991 was excluded (Table 3). Exclusion of the March 1991 datum did not significantly alter the regression (ANCOVA, $\mathrm{p}=0.679$ ). We believe that treatment of the March 1991 result as an outlier was justified for several reasons. Phytoplankton rate processes and biomass concentrations were unusually low during March 1991, as reported in earlier publications (Lohrenz et al. 1994, Redalje et al. 1994, Fahnenstiel et al. 1995), and this was attributed to a combination of seasonally low temperatures and greater average mixed layer depth (e.g. mean $=9.5 \mathrm{~m}$, standard deviation $=6.6 \mathrm{~m}, \mathrm{~N}=46 \mathrm{in}$ March 1991 compared with mean $=4.7$, $\mathrm{SD}=5.3, \mathrm{~N}=13$ in March 1993) The deeper mixing apparently resulted from a large pulse in river discharge relatively early in the year (Fig. 3a) that coincided with the seasonal minimum in water temperatures (usually around February, data not shown). A consequence of the deeper mixing was
Table 2. Results of $t$-test comparing mean primary production (PP) for plume and eastern regions

\begin{tabular}{|c|c|c|c|c|c|c|c|}
\hline \multirow[t]{2}{*}{ Date } & \multicolumn{2}{|c|}{ Mean PP } & \multicolumn{2}{|c|}{ SD } & \multicolumn{2}{|c|}{$N$} & \multirow{2}{*}{$\begin{array}{c}p(T \leq t) \\
(2 \text {-tail })\end{array}$} \\
\hline & Plume & Eastern & Plume & Eastern & Plume & Eastern & \\
\hline Jul-Aug 1990 & 3.8 & 3.7 & 3.1 & 0.61 & 21 & 2 & 0.98 \\
\hline Mar 1991 & 0.28 & 0.29 & 0.20 & 0.10 & 10 & 2 & 0.96 \\
\hline Apr 1992 & 1.9 & 1.2 & 0.41 & 0.066 & 5 & 2 & 0.065 \\
\hline May 1992 & 3.8 & 1.3 & 2.3 & 0.48 & 3 & 2 & 0.25 \\
\hline
\end{tabular}

Table 3. Relationships between primary production (PP) and river nutrient and freshwater inputs for data from 1988 to 1994. Data were natural log-transformed to normalize variances. $p$ is the 2 -tailed probability. 'Relationship was significant at or above the $95 \%$ confidence level

\begin{tabular}{|c|c|c|c|c|}
\hline Region & Relatıonship & $r^{2}$ & $\mathrm{p}$ & $N$ \\
\hline \multirow[t]{5}{*}{ Central/Eastern } & PP versus $\mathrm{NO}_{3}^{-}+\mathrm{NO}_{2}^{-}$flux & 0.196 & 0.129 & 13 \\
\hline & $\begin{array}{l}\text { PP versus } \mathrm{NO}_{3}{ }^{-}+\mathrm{NO} \text {, flux } \\
\text { (March } 1991 \text { outlier omitted) }\end{array}$ & 0.576 & $0.004^{\bullet}$ & 12 \\
\hline & PP versus $\mathrm{NO}_{3}^{-}+\mathrm{NO}_{2}^{-}$concentration & 0.385 & $0.024^{\circ}$ & 13 \\
\hline & PP versus $\mathrm{PO}_{4}{ }^{3-}$ concentration & 0.564 & 0.085 & 6 \\
\hline & PP versus discharge & 0.129 & 0.252 & 12 \\
\hline \multirow[t]{4}{*}{ Western } & $P P$ versus $\mathrm{NO}_{3}{ }^{-}+\mathrm{NO}_{2}{ }^{-}$flux & 0.158 & 0.143 & 15 \\
\hline & PP versus $\mathrm{NO}_{3}+\mathrm{NO}_{2}$ concentration & 0.074 & 0.326 & 15 \\
\hline & PP versus $\mathrm{PO}_{4}{ }^{3-}$ concentration & 0.007 & 0.841 & 8 \\
\hline & PP versus discharge & 0.113 & 0.220 & 15 \\
\hline Western & $\mathrm{PP}$ versus $\mathrm{NO}_{3}^{-}+\mathrm{NO}_{2}^{-}$flux & 0.121 & 0.224 & 14 \\
\hline (1 mo lag & PP versus $\mathrm{NO}_{3}^{-}+\mathrm{NO}_{2}^{-}$concentration & 0.103 & 0.263 & 14 \\
\hline between input & PP versus $\mathrm{PO}_{4}^{3-}$ concentration & 0.427 & 0.079 & 8 \\
\hline and PP) & PP versus discharge & 0.062 & 0.390 & 14 \\
\hline
\end{tabular}



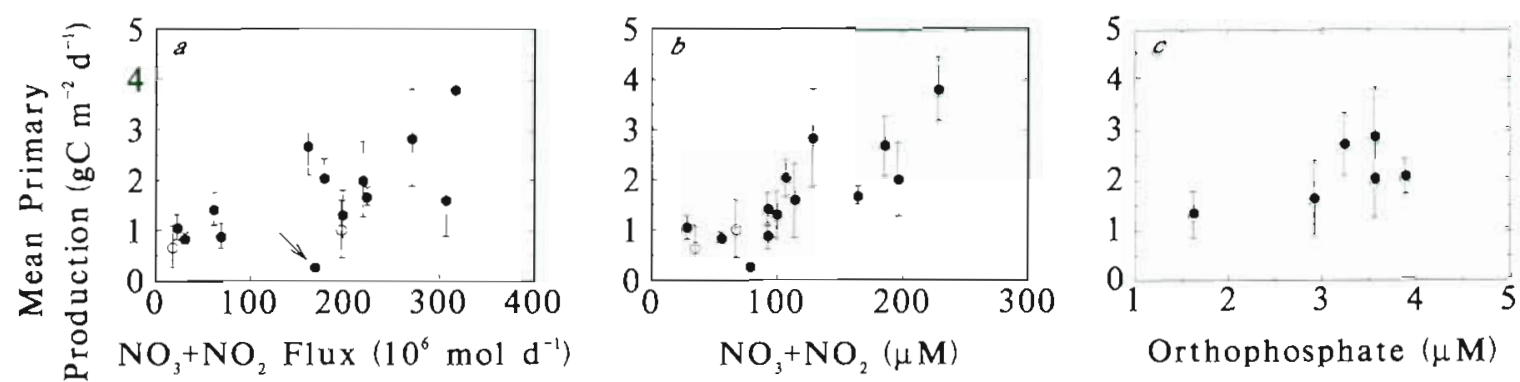

Fig. 4. Relationship between mean primary production for the combined central and eastern regions and (a) riverborne $\mathrm{NO}_{3}{ }^{-}+$ $\mathrm{NO}_{2}^{-}$flux, (b) $\mathrm{NO}_{3}{ }^{-}+\mathrm{NO}_{2}{ }^{-}$concentrations (at Venice), and (c) orthophosphate concentrations (at Belle Chase). Source of nutrient data as in Fig. 3. Arrow in (a) indicates March 1991 outlier (see text and Table 3). Historical primary production data (Thomas \& Simmons 1960) are included in (a) and (b) for comparison (o). Error bars indicate $\pm 1 \mathrm{SE}$

that rates of phytoplankton primary production were constrained by available light, leading to a lack of coupling between nutrient flux and productivity. In support of this argument, mean mixed layer irradiance for the combined eastern/central regions during March 1991 was lower than at any other time (Fig. 5).

The trend in Fig. 4a was statistically significant for the remaining data (Table 3), which encompassed a broad range of variations in primary production and river inputs and included periods of both annual maxima and minima in nutrient fluxes (Fig. 3b). A statistically significant trend was also clearly evident in the relationship between primary production and end-member $\mathrm{NO}_{3}{ }^{-}+\mathrm{NO}_{2}{ }^{-}$concentrations, even with the inclusion of the March 1991 datum (Fig. 4b, Table 3 ). The relationship between primary production and orthophosphate (Fig. 4c) was not significant (Table 3) although this analysis suffered from limited availability of orthophosphate data. An examination of relationships in the western region between primary

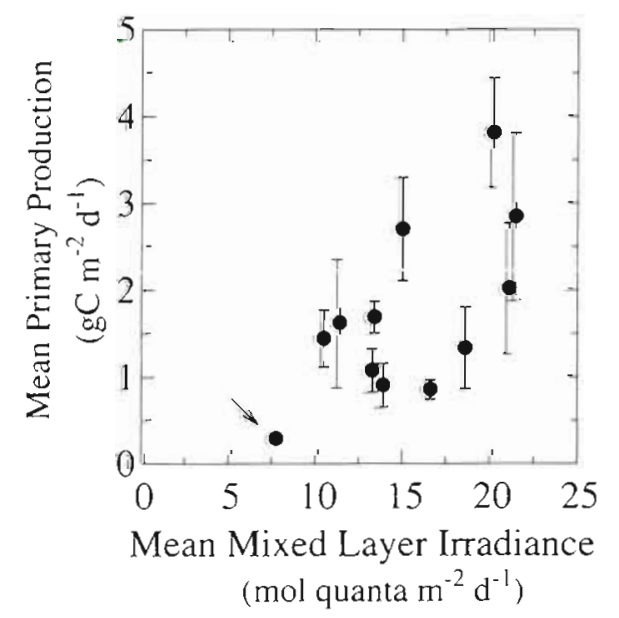

Fig. 5. Relationship between mean primary production for the combined central and eastern regions and mean mixed layer irradiance. Arrow indicates March 1991 outlier (see text). Error bars indicate $\pm 1 \mathrm{SE}$ production and nutrient flux and concentrations revealed no significant correlations, even if a 1 mo lag (cf. Justic et al. 1993) was assumed between river inputs and primary production (Table 3).

The apparent importance of light and temperature in constraining productivity during March 1991 gave rise to the question of the importance of these variables, relative to nutrient inputs, throughout the remaining data set. To examine this question, a stepwise multiple linear regression analysis was conducted using mean primary production as the dependent variable and $\mathrm{NO}_{3}{ }^{-}+\mathrm{NO}_{2}{ }^{-}$ flux, mean mixed layer irradiance and mean surface temperature as independent variables (Table 4). When all data were included, $\mathrm{NO}_{3}{ }^{-}+\mathrm{NO}_{2}^{-}$flux and temperature were excluded as variables (tolerance for exclusion was $\mathrm{p}=0.15$ ) and mean mixed layer irradiance was the best predictor, explaining $51 \%$ of the variance in mean primary production. However, if the March 1991 datum was omitted, then $\mathrm{NO}_{3}{ }^{-}+\mathrm{NO}_{2}{ }^{-}$flux was the best predictor with temperature explaining an additional portion of the residual variance. The 2 variables together accounted for $71 \%$ of the variance in mean primary production. The relationship was also examined with end-member $\mathrm{NO}_{3}{ }^{-}+\mathrm{NO}_{2}{ }^{-}$concentrations substituted for $\mathrm{NO}_{3}{ }^{-}+\mathrm{NO}_{2}{ }^{-}$flux (Table 4). When all data were included, both $\mathrm{NO}_{3}{ }^{-}+\mathrm{NO}_{2}^{-}$concentration and mean mixed layer irradiance were included as significant predictors; $66 \%$ of the variation in primary production was accounted for by the model. When the March 1991 datum was omitted, only $\mathrm{NO}_{3}{ }^{-}+\mathrm{NO}_{2}{ }^{-}$concentration was included as a significant predictor, accounting for $59 \%$ of the variation in mean primary production.

A comparison of historical data from the $1950 \mathrm{~s}$ (Thomas \& Simmons 1960) with the 1988 to 1994 data set (Fig. $4 \mathrm{a}, \mathrm{b}$ ) underscored the assertion that higher present-day $\mathrm{NO}_{3}{ }^{-}+\mathrm{NO}_{2}^{-}$fluxes and concentrations have been accompanied by increased primary production. The historical data included estimates of water columnintegrated primary production from November 1956 and May 1957, thus representing 2 different seasons and 
Table 4. Stepwise multiple linear regression analyses of the relationships between primary production (PP) versus river nutrient inputs, mean mixed layer irradiance and mean surface temperature for combined data from the central and eastern regions. Data were natural $\log$-transformed as in Table 3. Standardized coefficients represent the number of standard deviations that the dependent variable changes when an independent variable changes by 1 standard deviation (Wilkinson et al. 1996). - variable was excluded $(p>0.15)$. In all cases, collinearity of the independent variables was not significant $(p>0.05$, not shown)

\begin{tabular}{|c|c|c|c|c|c|c|}
\hline \multirow[t]{2}{*}{ Data used } & \multicolumn{3}{|c|}{ Standardized coefficients of independent variables } & \multirow[t]{2}{*}{ Multiple $r^{2}$} & \multirow[t]{2}{*}{$\mathrm{p}$} & \multirow[t]{2}{*}{$\mathrm{N}$} \\
\hline & $\mathrm{NO}_{3}{ }^{-}+\mathrm{NO}_{2}{ }^{-}$flux & Mixed layer ırrad. & Temperature & & & \\
\hline All data & - & 0.714 & - & 0.510 & 0.009 & 12 \\
\hline March 1991 omitted & 0.996 & - & 0.449 & 0.714 & 0.007 & 11 \\
\hline & $\mathrm{NO}_{3}^{-}+\mathrm{NO}_{2}^{-}$conc. & Mixed layer irrad. & Temperature & & & \\
\hline All data & 0.413 & 0.554 & - & 0.655 & 0.008 & 12 \\
\hline March 1991 omitted & 0.766 & - & - & 0.587 & 0.006 & 11 \\
\hline
\end{tabular}

river discharge levels. Values were near the low end of the range in productivity observed for 1988 to 1994 , but consistent with relationships between productivity and $\mathrm{NO}_{3}{ }^{-}+\mathrm{NO}_{2}{ }^{-}$flux and concentration (Fig. 4)

The utilization of the allocthonous nutrient inputs and subsequent transformation into plankton biomass would result in a net increment of organic matter to the proximal shelf ecosystem, and this would be equivalent to total primary production less the fraction supported by regenerated nutrients. Although direct measurements of nitrogen recycling and uptake rates were not available, it was possible to compare the riverborne $\mathrm{NO}_{3}{ }^{-}+\mathrm{NO}_{2}{ }^{-}$flux to the total nitrogen requirement for primary production in the delta region. Rates of primary production were converted from carbon to nitrogen units using Redfield carbon:nitrogen ele-

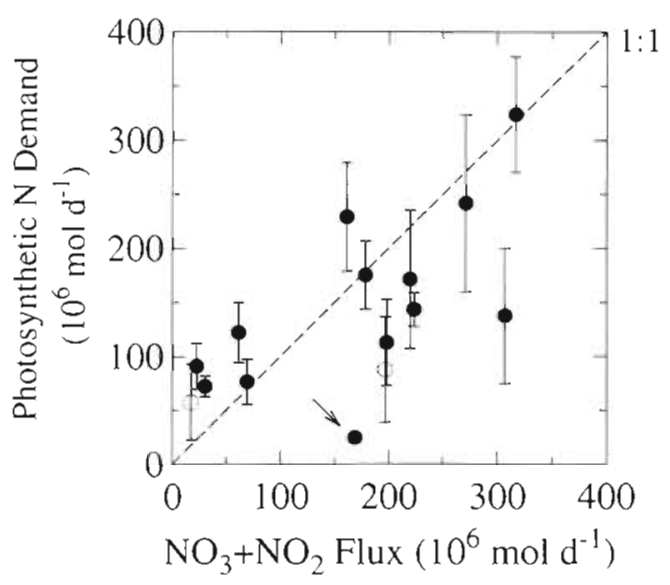

Fig. 6. Relationship between nitrogen requirements for phytoplankton primary production for the combined central and eastern regions and riverborne $\mathrm{NO}_{3}{ }^{-}+\mathrm{NO}_{2}{ }^{-}$flux. Arrow indicates March 1991 outlier (see text and Table 3). A significant correlation existed if the March 1991 datum was excluded $\left(r^{2}=0.196, p=0.129, N=13\right.$ with March 1991 datum; $r^{2}=0.576, p=0.004, N=12$ without March 1991 datum). Historical data (Thomas \& Simmons 1960) are shown for comparison $(0)$ and were not included in the correlation. Error bars indicate $\pm 1 \mathrm{SE}$ mental ratios (106:16). Areal nitrogen requirements were then estimated for the combined central/eastern region and compared to $\mathrm{NO}_{3}{ }^{-}+\mathrm{NO}_{2}{ }^{-}$flux from the river (Fig. 6). As for the case of mean primary production in Fig 4a, the relationship exhibited a positive correlation provided that the March 1991 datum was excluded. The results in Fig. 6 further illustrate that nitrogen requirements for phytoplankton primary production in the combined central/eastern region were often comparable in magnitude to the $\mathrm{NO}_{3}{ }^{-}+\mathrm{NO}_{2}{ }^{-}$flux.

\section{DISCUSSION}

Our findings provide direct evidence of a temporal relationship between riverborne nutrient fluxes and primary production in continental shelf waters of the northern Gulf of Mexico. Measured primary production in a $6800 \mathrm{~km}^{2}$ region (eastern and central boxes) near the river delta was found to be significantly correlated with nitrate + nitrite $\left(\mathrm{NO}_{3}{ }^{-}+\mathrm{NO}_{2}{ }^{-}\right)$concentrations and fluxes over a 6 yr period from 1988 to 1994 (Fig. 4, Table 3). An outlier in March 1991 was apparently influenced by constraints on primary production due to low available irradiance (Table 4). Light was less important as a constraining variable in the remaining data collected during other times of the year; peak nitrogen fluxes typically occurred in spring (Fig. 3b).

A comparison of the estimated nitrogen uptake by phytoplankton with the river-borne supply of $\mathrm{NO}_{3}{ }^{-}+$ $\mathrm{NO}_{2}{ }^{-}$nitrogen (Fig. 6) revealed that fluvial inorganic nitrogen flux was equivalent to a large proportion of photosynthetic nitrogen requirements (mean $=106 \%$, $\mathrm{SD}=58 \%, \mathrm{~N}=12$, March 1991 excluded). This situation was in contrast to conditions reported for the Amazon shelf, where regeneration was estimated to sustain $>50 \%$ of nitrogen requirements for primary production (DeMaster \& Pope 1996). The differences in nitrogen utilization between the Mississippi and Amazon ecosystems could be due to a large extent to the much higher river end-member concentrations of 
nitrate in the Mississippi as compared to the Amazon River. DeMaster \& Pope (1996) reported an endmember concentration range for $\mathrm{NO}_{3}{ }^{-}$in the Amazon River of 12 to $23 \mu \mathrm{mol} \mathrm{kg}{ }^{-1}$ ( $\mu \mathrm{M}$ ) as opposed to the range of 20 to $240 \mu \mathrm{M}$ for the Mississippi River at Venice (Fig. 3a). This difference was presumably a reflection of greater anthropogenic impact on the Mississippi River system.

Despite the relatively high concentrations of nutrients in the Mississippi River, biological uptake within. the central and eastern regions was often comparable in magnitude to inputs (Fig. 6). For such cases, we conclude that river-borne nutrients were rapidly transformed into organic matter in this system. Independent support for this conclusion comes from observations that surface nitrate concentrations typically declined to near zero within 20 to $100 \mathrm{~km}$ of the river delta (Lohrenz et al. 1990, 1992, unpubl.). The particularly strong correlation between primary production and end-member $\mathrm{NO}_{3}{ }^{-}+\mathrm{NO}_{2}{ }^{-}$concentrations (Fig. 4b, Tables $3 \& 4$ ) could be explained if nutrients supplied by the river were rapidly consumed, thereby setting an upper limit on the yield of phytoplankton biomass in plume waters. Previous studies have demonstrated that a large proportion of the variance in primary production can be explained by variations in chlorophyll (Lohrenz et al. 1990, Redal.je et al. 1994). However, the simplified concept of a steady-state relationship between end-member nutrient concentrations, biomass and primary production is clearly inadequate to fully describe the system. For example, biomass distributions can potentially be influenced by other factors such as light limitation (Wofsy 1983) and temporal deviations between phytoplankton growth and loss rates (Malone et al. 1996). Furthermore, biomassspecific primary production has been shown to vary spatially and temporally in the region of the Mississippi River outtlow (Lohrenz et al. 1994).

As river-borne nutrients become depleted, the relative importance of other nutrient sources will increase, reducing the direct coupling between primary production and river inputs. The importance of biological regeneration of nutrients in this ecosystem has been evidenced by prior observations of surface nutrient properties (Dortch \& Whitledge 1992), close coupling between primary producers and heterotrophic compartments (Gardner et al. 1994, Dagg 1995, Fahnenstiel et al. 1995), and high benthic nutrient fluxes (Murphy et al. 1975). Mississippi River nitrogen fluxes may also be supplemented by upwelled nitrogen sources (López-Veneroni \& Cifuentes 1994) and contributions from the Atchafalaya River located to the west of the study area. Finally, the contributions of dissolved organic nitrogen (DON) and particulate organic nitrogen (PON) have not been considered in our flux esti- mates. These constituents can represent substantial fractions of the total nitrogen in river water (e.g. means of $34 \%$ for DON and $12 \%$ for PON for 1988 to 1994 USGS data from Venice). However, the extent to which these polential sources supplement the nitrogen available for uptake by phytoplankton is uncertain. A portion of the riverine DON pool is likely to be refractory. The proportion of total dissolved nitrogen associated with DON has been shown to increase with increasing salinity (López-Veneroni \& Cifuentes 1994), apparently the result of both preferential depletion of inorganic nitrogen pools and in situ production of DON. Particulate organic matter concentrations in the Mississippi River have been shown to be well correlated with total suspended matter concentrations, which decrease sharply within a few $\mathrm{km}$ of the river mouth (Trefry et al. 1994). Thus, a potentially large fraction of the river-borne particulate organic matter is initially deposited near the mouth. Release of nutrients from fluvial particles, either through desorption or remineralization, may subsequently contribute to the available inorganic nitrogen in the river plume

Rapid utilization of nutrients from the river may be an explanation for our inability to demonstrate a significant relationship between river-borne nutrient fluxes and primary production in the western region (Table 3). The temporal relationship of primary production to river $\mathrm{NO}_{3}{ }^{-}+\mathrm{NO}_{2}$ flux was likely obscured in the western region by other nitrogen sources, particularly if the dynamics of such inputs were not correlated with the river-borne inorganic nitrogen flux. Despite the lack of a temporal relationship in the western region, nutrient impacts of the river would be likely to extend, as a result of advection of organic matter and successive remineralization and uptake, far beyond the region where river-borne nutrients were consumed. A key question that remains unresolved in this ecosystem is the fate of the organic matter produced as a result of elevated primary production in the river-impacted waters. The narrow extent of the shelf near the delta (Fig. 2) may lead to some export of organic matter off the shelf. However, a strong alongshore component of the coastal currents in this region (Cochrane \& Kelly 1986, Wiseman \& Garvine 1995) probably results in a major portion of newly produced organic matter being transported along the shelf.

Possible fates of the nutrient-enhanced primary production in continental shelf waters include sedimentation (Smetacek 1984) resulting in greater likelihood for development of hypoxic conditions in benthic environments (Justic et al. 1993). Hypoxic bottom waters ( $\leq 2 \mathrm{mg} \mathrm{l}^{-1}$ or $62.5 \mu \mathrm{M}$ dissolved oxygen) on the Louisiana continental shelf can cover an area up to $9000 \mathrm{~km}^{2}$ during summer (Rabalais et al. 1994, Turner \& Rabalais 1994b), thus comprising one of the largest 
hypoxic zones in continental shelf waters. Hypoxic conditions have been shown to have adverse effects on macrobenthic communities (Gaston 1985, Dauer et al. 1992) and may negatively impact commercially important species such as shrimp, which comprise a valuable fishery in the Gulf of Mexico (Newlin 1993).

Because our data set spans only a 6 yr period, it cannot be used, by itself, to infer decadal trends in productivity. Interannual and intra-annual variations obscured any extended trends in the observations (Fig. 3). However, a comparison of our observations with historical measurements of primary production near the Mississippi delta (Thomas \& Simmons 1960) in relation to corresponding river discharge levels and nutrient inputs (Figs. 4 \& 6) supported arguments that recent rates of primary production have reached higher levels. The fact that nutrient concentrations and fluxes have increased dramatically in the Mississippi River over the past 35 yr (Turner \& Rabalais 1991, Dinnel \& Bratkovitch 1993, Bratkovich et al. 1994), together with the observed coupling between nutrient inputs and productivity demonstrated by this study also supports arguments for a long-term effect on primary production.

Although it is tempting to extrapolate the relationships in Figs, 4 \& 6, such an exercise must be interpreted with caution. The implication of such an extrapolation is that additional increases in primary production will accompany further increases in nutrient inputs from the river, and this could increase the frequency and severity of hypoxia events. However, such relationships are unlikely to be linear; other factors such as light and food web interactions will inevitably influence the outcome of changing nutrient inputs. In addition, because a complete understanding of processes intermediate between primary production of organic matter and oxygen depletion in bottom. waters on the Louisiana shelf is still lacking, the consequences of increases in current levels of primary production are also difficult to predict. Accurate predictions can be achieved only through comprehensive temporal and spatial characterization of the physical dynamics of the ecosystem in relationship to the biogeochemical cycling of organic matter and its transport along the continental shelf.

Acknowledgements. Financial support for this research was provided by the NOAA Coastal Ocean Program through Mississippi-Alabama Sea Grant (NA90AA-D-SG688, project no. R/LR-25), by the U.S. Department of Energy (DE-FG0292ER61663, DE-FG05-95ER62071, and DE-FG0292ER61414), by the U.S. Minerals Management Service (OCS contract no. 14-35-0001-30509), and by the Board of Regents of the State of Louisiana (Contract no. 86-LUM(1)-083-13). We are grateful for the technical assistance of $\mathrm{H}$. Carrick, J. Cavaletto, B. Chen, Y Chen, R. Krest, M. Markowitz, J. Hendee, D. Taylor and C. Rathbun. G. Hitchcock provided pigment data from Baldrige cruises. D. Wiesenburg generously provided cruise and logistical support for RV 'Powell' cruises. We are grateful to the U.S. Army Corps of Engineers for river discharge data and to the U.S. Geological Survey for nutrient data. S. Dinnel and A. Bratkovich provided helpful comments. We also thank the Captains and crews of the RV 'Pelican', the NOAA Ship 'Malcom Baldrige', and the RV 'Powell' USM Contribution No. 0188

\section{LITERATURE CITED}

Bratkovich A, Dinnel SP, Goolsby DA (1994) Variability and prediction of freshwater and nitrate fluxes for the Lousiana-Texas shelf: Mississippi and Atchafalaya River source functions. Estuaries 17:766-778

Bricker SB, Stevenson JC (1996) Nutrients in coastal waters: a chronology and synopsis of research. Estuaries 19:337-341

Cochrane JD, Kelly FJ (1986) Low-frequency circulation on the Texas-Louisiana shelf. J Geophys Res 91:10645-10659

Dagg MJ (1995) Copepod grazing and the fate of phytoplankton in the northern Gulf of Mexico. Cont Shelf Res 15:1303

Dauer DM, Rodi AJ Jr, Ranasinghe JA (1992) Effects of low dissolved oxygen events on the macrobenthos of the lower Chesapeake Bay. Estuaries 15:384-391

DeMaster DJ, Pope R (1996) Nutrient dynamics in Amazon shelf waters: results from AMASSEDS. Cont Shelf Res 16: 263-289

DeMaster DJ, Smith WO Jr, Nelson DM, Aller JY (1996) Biogeochemical processes in Amazon shelf waters: chemical distributions and uptake rates of silicon, carbon and nitrogen. Cont Shelf Res 16:617-643

Dinnel SP, Bratkovitch A (1993) Water discharge, nitrate concentration and nitrate flux in the lower Mississippi River. J Mar Syst 4:315-326

Dortch Q, Whitledge TE (1992) Does nitrogen or silicon limit phytoplankton production in the Mississippi River plume and nearby regions? Cont Shelf Res 12:1293-1309

Dyer K, D'Elia C (eds) (1994) Changes in fluxes in estuaries: implications from science to management. International Symposium Series, No. 22. Olsen and Olsen, Fredensborg

Fahnenstiel GL, McCormick MJ, Lang GA, Redalje DG, Lohrenz SE, Markowitz M, Wagoner B, Carrick HJ (1995) Taxon-specific growth and loss rates for dominant phytoplankton populations from the northern Gulf of Mexico Mar Ecol Prog Ser 117:229-239

Fishman MJ, Friedman L.C (1989) Methods for determination of inorganic substances in water and fluvial sediments. US Geological Survey Techniques of Water-Resources Investigations, Book 5, Chap A1, Denver

Gardner WS, Benner R, Chin-Leo G, Cotner JB Jr, Eadie BJ Cavaletto $J F$, Lansing MB (1994) Mineralization of organic material and bacterial dynamics in Mississippi River plume water. Estuaries 17:816-828

Gaston GR (1985) Effects of hypoxia on macrobenthos of the inner shelf off Cameron, Louisiana. Estuar Coast Shelf Sci 20:603-613

Hinga KR, Jeon H, Lewis NF (eds) (1995) Marine eutrophication review-Part 1. Quantifying the effects of nitrogen enrichment on phytoplankton in coastal ecosystems; Part 2: Bibliography with abstracts. NOAA Coastal Ocean Program Decision Analysis Series, No. 4. National Oceanic and Atmospheric Administration Coastal Ocean Office, Silver Spring, MD

Justic D, Rabalais NN, Turner RE (1994) Riverborne nutrients, hypoxia and coastal ecosystem evolution: biological re- 
sponses to long-term changes in nutrient loads carried by the Po and Mississippi Rivers. In: Dyer KR, Orth RJ (eds) Changes in fluxes in estuaries: implications from science to managenent. ERF Symposium, ECSA22. Olsen and Olsen, Fredensborg, p 161-167

Justic D, Rabalais NN, Turner RE, Wiseman WJ Jr (1993\} Seasonal coupling between riverborne nutrients, net productivity and hypoxia. Mar Pollut Bull 26:184-189

Lang GA, Fahnenstiel GL (1996) Great lakes primary production model-methodology and use. NOAA Tech Memo ERL GLERL-90, Ann Arbor, MI

Laws E (ed) (1997) Mathematical methods for oceanographers. John Wiley \& Sons, New York

Lew1s MR, Smith JC (1983) A small-volume, short-incubation time method for the measurement of photosynthesis as a function of incident irradiance. Mar Ecol Prog Ser 13:99-102

Lohrenz SE (1993) Estimation of primary production by the simulated in situ method. ICES Mar Sc Symp 197:159-171

Lohrenz SE, Dagg MJ, Whitledge TE (1990) Enhanced primary production at the plume/oceanic interface of the Mississippi River. Cont Shelf Res 10:639-664

Lohrenz SE, Fahnenstiel GL, Redalje DG (1994) Spatial and temporal variations of photosynthetic parameters in relation to environmental conditions in northern Gulf of Mexico coastal waters. Estuaries 17:779-795

Lohrenz SE, Fahnenstiel GL, Redalje DG, Lang GA (1992) Regulation and distribution of primary production in the northern Gulf of Mexico. In: NOAA Coastal Ocean Program (ed) Nutrient Enhanced Coastal Ocean Productivity, NECOP Workshop Proceedings, October 1991. Texas Sea Grant Publications, College Station, TX, TAMU-SG-92109, p 94. 104

Lohrenz SE, Wiesenburg DA, Arnone RA, Chen X (1998) What controls primary production in the Gulf of Mexico? In: Kumpl H, Sheman K, Steidinger K (eds) Proceedings of the Gulf of Mexico: a large marine ecosystem symposium. Blackwell Scientific, Cambridge (in press)

López-Veneroni D, Clfuentes LA (1994) Transport of dissolved organic nitrogen in Mississippi River plume and Texas-Louisiana continental shelf near-surface waters Estuaries 17:796-808

Malone TC (1984) Anthropogenic nitrogen loading and assimilation capacity of the Hudson Ruver estuarme system, USA. In: Kennedy VS (ed) The estuary as a filter Academic Press, Orlando, p 291-311

Malone TC, Conley DJ, Fisher TR, Glibert PM, Harding LW, Sellner KG (1996) Scales of nutrient-limited phytoplankton productivity in Chesapeake Bay. Estuaries 19: $371-385$

Müller-Karger FE, Walsh JJ, Evans RH, Meyers MB (1991) On the seasonal phytoplankton concentration and sea surface temperature cycles of the Gulf of Mexico as determined by satellites. J Geophys Res 96:12645-12665

Murphy EB, Steidinger KA, Roberts BS, Williams J, Jolley JW Jr (1975) An explanation for the Florida east coast Gymnodinium breve red tide of November 1972. Limnol Oceanogr 20:481-486

Newlin K (ed) (1993) Fishing trends in the Southeast Region, 1994. U.S. Department of Commerce, NOAA/NMFS Miami, FL, NOAA Tech Memo NMFSS-SRFSC-354

Rabalais NN, Turner RE, Justic D, Dortch Q, Wiseman WW Jr,

This article was submitted to the editor
Sen Gupta BK (1996) Nutrient changes in the Mississipp River and system responses on the adjacent continental sheif. Estuaries 19:386-407

Rabalais NN, Turner RE, Wiseman WJ Jr (1994) Hypoxic conditions in bottom waters on the Louisiana-Texas shelf. In Dowgiallo MJ (ed) Coastal oceanographic effects of summer 1993 Mississippi River flooding. Special NOAA Report. NOAA Coastal Ocean Office/National Weather Service Silver Spring, MD

Redalje DG, Lohrenz SE, Fahnenstiel GL (1994) The relationship between primary production and the vertical export of particulate organic matter in a river impacted coastal ecosystem. Estuaries 17:829-838

Riley GA (1937) The significance of the Mississippi River drainage for brological conditions in the northern Gulf of Mexico. J Mar Res 1:60-74

Ryther JH, Dunstan WM (1971) Nitrogen, phosphorus, and eutrophication in the coastal manne environment. Science 171:1008-1013

Smetacek $V$ (1984) The supply of food to the benthos. In: Fasham MJR (ed) Flows of energy and materials in marine ecosystems, theory and practice. Plenum Press, New York, p $517-547$

Smith WO, DeMaster DJ (1996) Phytoplankton biomass and productivity in the Amazon River plume: correlation with seasonal river discharge. Cont Shelf Res 16:291-319

Thomas WH. Simmons EG (1960) Phytoplankton production in the Mississippi Delta. In: Shepard F (ed) Recent sediments, Northwest Gulf of Mexico. American Association of Petrologists, Tulsa, OK, p 103-116

Trefry JH, Metz S, Nelsen TA, Trocine RP, Eadie BJ (1994) Transport of particulate organic carbon by the Mississippi River and its fate in the Gulf of Mexico. Estuaries 17 . $839-849$

Turner RE, Rabalais NN (1991) Changes in the Mississippi River qualsty in this century. BioSct 41:140-147

Turner RE, Rabalais NN (1994a) Changes in the Mississippl River nutrient supply and offshore silicate-based phytoplankton community responses. In: Dyer KR, Orth RJ (eds) Changes in fluxes in estuaries: implications from science to management. ECSA22/ERF Symposium. Olsen and Olsen, Fredensborg, p 147-150

Turner RE, Rabalais NN (1994b) Coastal eutrophication near the Mississippi River delta. Nature 368:619-621

van der Leeden F, Troise FL, Todd DK (eds) (1990) The water encyclopedia, 2nd edn. Lewis Publishers, Boca Raton, FL

Walker ND, Rouse LJ (1993) Satellıte assessment of Missıssippi River discharge plume variability. OCS Study MMS 93-0044, U.S. Dept of the Interior, Mineral Management Service, Gulf of Mexico OCS Regional Office, New Orleans, LA

Walsh JJ, Dieterle DA, Meyers MB, Müller-Karger FE (1989) Nitrogen exchange at the continental margin: a numerical study of the Gulf of Mexico. Prog Oceanogr 23:245-301

Wilkinson L, Blank G, Gruber C (1996) Desktop data analysis with SYSTAT Prentice Hall, Upper Saddle River, NJ

Wiseman WJ Jr, Garvine RW (1995) Plumes and coastal currents near large nver mouths. Estuaries 18:509-517

Wofsy SC (1983) A simple model to predict extunction coefficients and phytoplankton biomass in eutrophic waters. Limnol Oceanogr 28:1144-1155

Manuscript received: September 30,1996 Revised version accepted: June 10,1997 